\title{
Small-scale interactions between prions Pachyptila spp. and their zooplankton prey at an inshore site near Bird Island, South Georgia
}

\author{
Catherine Goss ${ }^{1, *}$, Douglas G. Bone ${ }^{1}$, Julie M. Peck ${ }^{1}$, Inigo Everson ${ }^{1}$, \\ George L. Hunt $\mathrm{Jr}^{2}$, Alistair W. A. Murray ${ }^{1}$ \\ ${ }^{1}$ British Antarctic Survey, Natural Environment Research Council, Madingley Road, High Cross, Cambridge CB3 0ET, \\ United Kingdom \\ ${ }^{2}$ Department of Ecology and Evolutionary Biology, University of California, Irvine, California 92697-2525, USA
}

\begin{abstract}
We investigated the relationship between surface-foraging prions Pachyptila spp. and their zooplankton prey by comparing counts of foraging birds with near-surface concentrations of zooplankton from net samples, Zooplankton abundance was assessed by employing a new design of sampler that combined a frame net with a pump at the cod-end and which was deployed at the sea surface. Six transects using the sampler with concurrent bird observations were made over a short stretch of Stewart Strait near Bird Island, South Georgia. Concentrations of a variety of zooplankton species occurred patchily along each transect. Peak numbers of prions were recorded consistently towards the southern end of each transect. These peaks coincided with peaks in zooplankton numbers, but with different prey species predominant on different occasions. Comparison of the distribution of foraging and sitting birds with the presence or absence of zooplankton peaks, after pooling zooplankton species into 2 broad classes, showed that birds were consistently observed over copepod maxima, but were not found to be associated with aggregations of larger zooplankton more often than expected by chance.
\end{abstract}

KEY WORDS: Seabirds - Zooplankton · Sampling · Antarctic marine inshore · Predation

\section{INTRODUCTION}

Predators are expected to concentrate their foraging in patches where prey are abundant, as long as the cost of travel to and between patches is negligible and prey in the different patches are equally accessible. Recent efforts to test this prediction using foraging seabirds and their prey have revealed weaker correlations between predator abundance and prey biomass than expected, particularly at small measurement scales (Obst 1985, Schneider \& Piatt 1986, Heinemann et al. 1989, Erikstad et al. 1990, Hunt \& Harrison 1990. Hunt et al. 1992). Explanations for the mismatch between predator abundance and prey biomass have included the apparent failure of diving birds to detect the highest density mid-water patches of zooplankton

•E-mail: c.goss@bas.ac.uk prey (Woodby 1984, Hunt \& Harrison 1990, Hunt et al. 1992), and the possibility that nocturnally foraging predators, when detected on the water during the day, may have drifted away from the prey patches on which they previously fed (Veit et al. 1993). Correlations between concurrent observations of densities of prey and diurnally foraging seabirds that capture their prey at the surface should be less subject to these sources of error, and thus are expected to be strong relative to correlations between prey biomass and sub-surfaceforaging birds or birds that forage at night. We therefore sought the opportunity to investigate the distribution and abundance of a surface-foraging seabird with respect to near-surface concentrations of prey.

Prions are conspicuous members of the avifauna in the South Atlantic with a breeding population of the order of 20 million at South Georgia (Croxall \& Prince 1987); they are one of the most important avian consumers of marine organisms at South Georgia (Croxall 
et al. 1985). Large numbers were observed around the islands on this survey (Hunt et al. 1986, Harrison et al. 1991). Several studies of the diet of Antarctic prions have been carried out at South Georgia (e.g. Prince 1980 , Liddle 1994, Reid et al. 1997). They indicated that prions are shallow divers, and that their bill morphology includes lamellae that enable them to harvest small zooplankton largely unexploited by other krill-eating seabirds at South Georgia (see Prince 1980). The diet samples from these studies always came from birds sampled after dark as they returned to feed their chicks; there could be differences between these samples and the food taken during the daytime observations described in the present paper.

Observations made at sea on the interactions between Antarctic birds and their prey have used both acoustics and traditional nets to survey prey species (Obst 1985, Heinemann et al. 1989, Hunt et al. 1992), but prions feed in the surface layer not assessed by standard versions of these techniques. For this reason, we carried out near-surface zooplankton sampling using a new design of pumped net with concurrent bird observations. This sampler could be deployed from a crane on the foredeck of the RRS 'John Biscoe' in a manner that permitted sampling of prey where prions had foraged moments before. This technique was particularly suitable for detecting small-scale patchiness because exact volumes of water can be filtered. Most pump sampling is carried out from a stationary platform, but the combination net and pump system described here enabled sampling to be carried out while the ship travelled at around 3 knots.

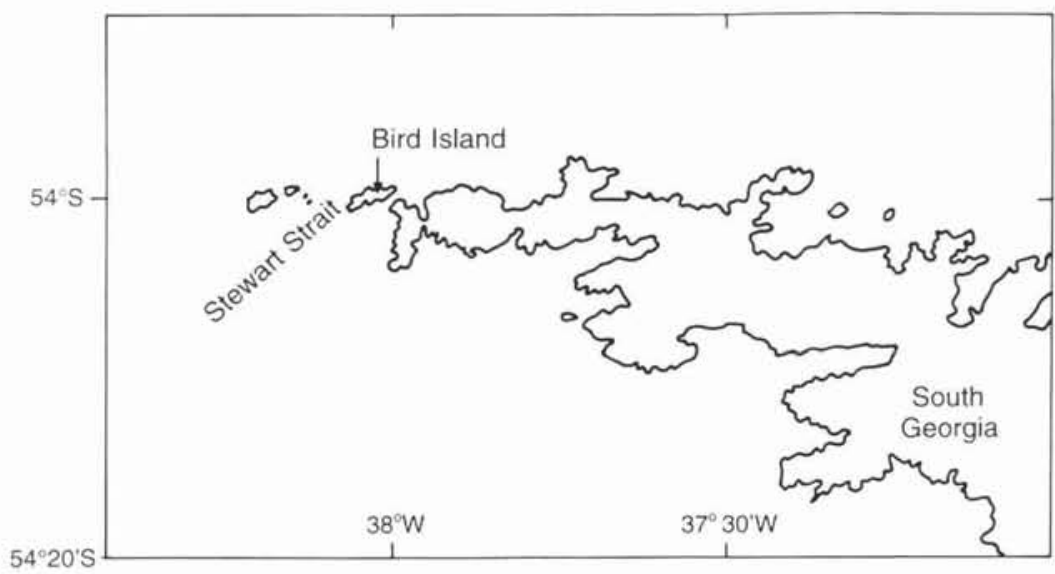

Fig. 1. Map of the study area

In this paper, we describe the new design of pump sampler for zooplankton, and we present the distribution and abundance of foraging prions with respect to the distribution and abundance of near-surface zooplankton populations in the same area.

\section{METHODS}

Survey site. In March 1986, during a research cruise on the RRS 'John Biscoe' in the waters around South Georgia, we made several series of observations close inshore during repeated transects through Stewart Strait. Stewart Strait is a channel between Bird Island and the Willis Islands at the northwestern end of South Georgia, and is $3.7 \mathrm{~km}$ wide at its narrowest point (Fig. 1). The channel is restricted by the shallow, irregular bottom: the depth ranged from 27 to $103 \mathrm{~m}$ during all the transects, averaging $70 \mathrm{~m}$; a shallow sill crosses the strait and is shown in the echogram in Fig. 2. All 6 runs were made when the tide was flooding, but the

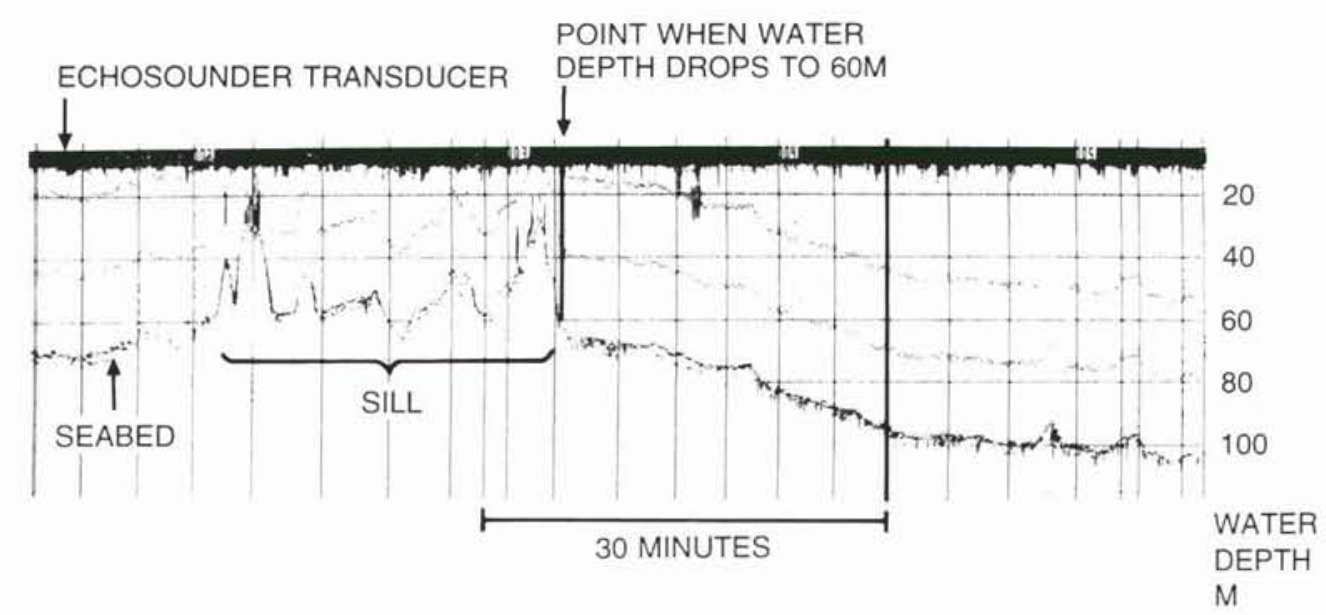

Fig. 2. An echochart recorded along one of the transects. The 2 light lines following the seabed contours are layer lines added by the echointegration system 
Table 1. Details of the 6 repeat transects made through Stewart Strait, South Georgia

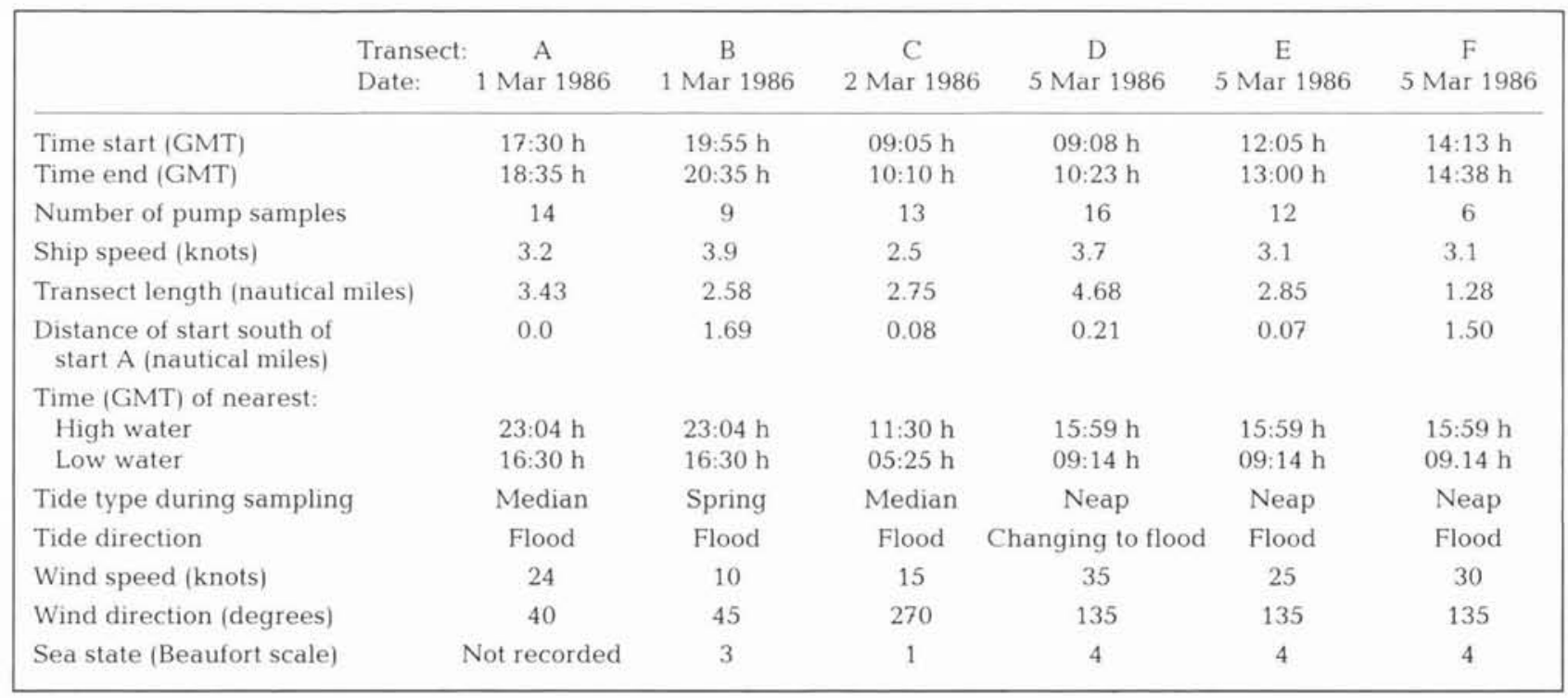

tidal range was less for the last 3 runs than for the first 3. The tidal stream floods to the south in Stewart Strait (Anon 1974), and though the tidal range is small, strong currents in the strait are reported by members of the British Antarctic Survey's Research Station at Bird Island. Wind speed and direction recorded at the time of sampling are shown in Table 1.

Survey details. Table 1 summarises the details of the 6 repeat transects made through Stewart Strait. All transects were from north to south. The size of the ship limited manouverability so that it was not possible to start sampling at exactly the same spot on each occasion. The transects all covered the same ground in the middle of the strait, and the extent of the overlap of each repeat is indicated in Table 1 by the offset from the most northerly start point (that of Transect A). The start and end times given (in GMT) are for the first and last zooplankton samples taken. Bird observations were made over longer periods.

Zooplankton sampling. Near-surface zooplankton was sampled using a new design of pump sampler deployed from the foredeck of the vessel and towed within the top metre of water. This sampler consisted of a net, the cod-end of which was continuously cleaned by an electrically driven submersible pump that delivered water to the ship's deck via a flexible tube (Fig. 3). On deck the particulate fraction was concentrated in sieves that were changed every $5 \mathrm{~min}$, and their catch was bottled in buffered formaldehyde solution. After samples were fixed in the buffered formalin they were stored in Steadman's solution, before being returned to the United Kingdom for sorting, identification and counting under a stereo microscope.

The net and pump were mounted in a frame as shown in Fig. 3. The overall length of the sampler was $3.5 \mathrm{~m}$ and the mouth area of the entrance cone was $0.25 \mathrm{~m}^{2}$. The net, whose mesh aperture was $1.6 \mathrm{~mm}$ (open area $60 \%$ ), was $600 \mathrm{~mm}$ diameter at the mouth and tapered to $55 \mathrm{~mm}$ diameter over $2.2 \mathrm{~m}$ giving a total filtering area of $2.3 \mathrm{~m}^{2}$. The net was towed at approximately 3 knots, giving an approximate volume filtered per $5 \mathrm{~min}$ sample of $116 \mathrm{~m}^{3}$. The pump deliv-

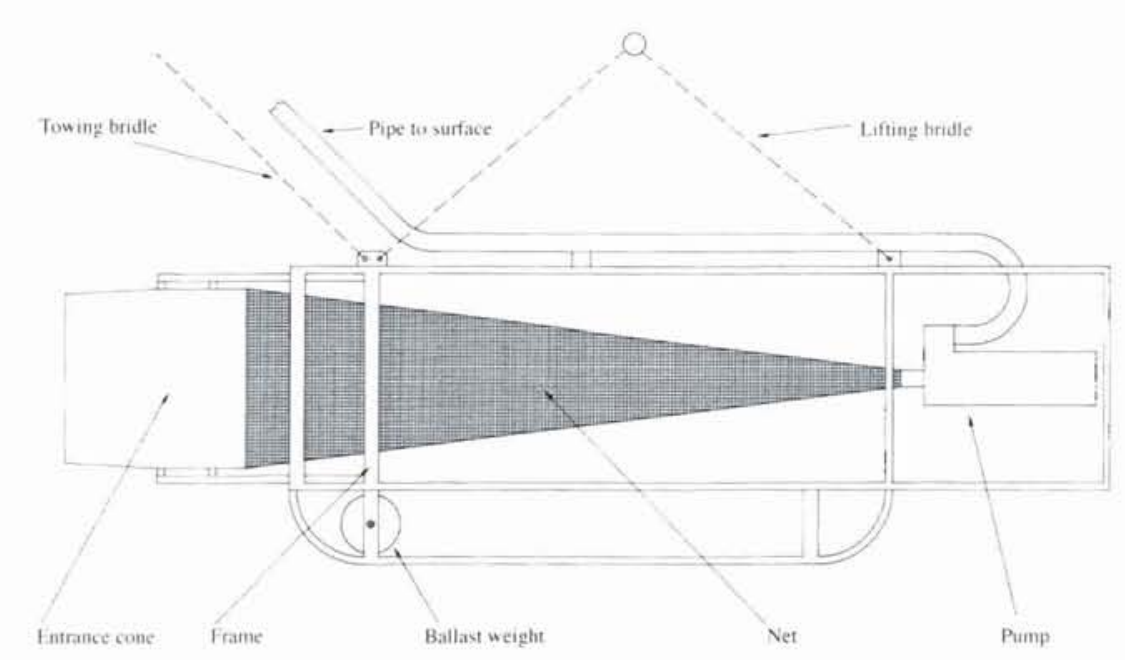

Fig. 3. Pump sampler 
ered the sample onto the deck at a rate of $2501 \mathrm{~min}^{-1}$ (4.166 $\left.\mathrm{l} \mathrm{s}^{-1}\right)$, producing a velocity of $1.75 \mathrm{~m} \mathrm{~s}^{-1}$ ( 3.5 knots) at the intake. The mesh aperture of the sieves was $1.0 \mathrm{~mm}$.

To relate zooplankton numbers to biomass we used length/weight measurements available in the literature, except in the case of individuals identified as either Thysanoessa vicina or T. macrura for which the required measurements were taken from specimens obtained in this study. Because we only made counts of other species in the samples, biomass estimates were approximate. They were used to separate the taxa into 2 groups for analysis, copepods and larger zooplankton. The copepods were about 10 times smaller (by dry weight) than zooplankton in the 'larger zooplankton' group; in plotting zooplankton numbers, the $y$-axes have been scaled to be approximately equivalent in terms of biomass.

Acoustic observations. A Simrad EK400 Echosounder was used throughout the sampling period, operating at frequencies of 38 and $120 \mathrm{kHz}$; echoes were recorded onto charts. A section of echochart from 1 transect is reproduced in Fig. 2. This represents a composite picture, recording alternate pings from the 2 frequencies. The transducers were mounted in the bottom of the hull, about $5 \mathrm{~m}$ below the water surface. Echoes from the first few metres below the transducer cannot be used because of beam characteristics and the obscuring effect of the bubble layer at $38 \mathrm{kHz}$, so the shallowest water depth from which useful echoes were recorded was $10 \mathrm{~m}$. This is well below the depth at which the prions that we observed were feeding, therefore acoustic results were only used for the bathymetric record they provide. The sill apparent in Fig. 2 was also clearly visible on the other 5 transects. Owing to the very irregular nature of the seabed, and the fact that each transect covered a slightly different track, the shallowest depth was not the most useful record of the sill's location. At the southern edge of the sill the water depth increased comparatively smoothly until the water was deeper than in the northern part of the strait. We designated the southern edge of the sill on each transect as the point where the depth reached $60 \mathrm{~m}$ (the thick vertical line in Fig. 2). This provided a reference location that was related each time to the sill, but independent of the irregular shallowest section.

Seabird observations. Observations of birds were made concurrently with the pump sampling. Observers counted birds from the bridge-wing, $10 \mathrm{~m}$ above the water, on the side of the vessel from which the pump sampler was deployed. A square area of sea extending $100 \mathrm{~m}$ ahead of the ship and $90^{\circ}$ to the side of the mid-line for a distance of $100 \mathrm{~m}$ was watched continuously and observations were entered simultaneously on a microcomputer, recorded to the nearest
$0.1 \mathrm{~min}$. Assuming an average speed of 3 knots, the $100 \mathrm{~m}$ ahead of the ship could mean that the bird observations were made up to 1 min ahead of the zooplankton observations or the echograms. In addition to the time of observation, the behaviour of each bird was recorded. Only 3 classes were used to distinguish the behaviour of prions: (1) flying; (2) sitting on the water; (3) feeding. Some analyses were carried out using all bird records, and further tests were carried out excluding flying birds. Inclusion of flying birds in this instance is appropriate because we are concerned with relative numbers along a short transect.

No distinction was made between the 2 species of prions encountered in the area, because this is not possible with observations made at the range described. The vast majority of prions in the area are Pachyptila desolata which outnumber $P$. turtur by over 20000 to 1 in terms of the breeding population (Croxall \& Prince 1987).

Data analysis. Data were stored on a VAX 8350 computer in the British Antarctic Survey's Marine Life Sciences ORACLE Database. Data on birds, zooplankton, bathymetry and geographical location were related to each other using time, and the relationships between these variables (and log transformations of animal numbers) were examined using the statistical package GENSTAT Version 5.2 (Payne et al. 1987). Autocorrelation and cross-correlation tests were performed on the zoological data, using standard tests for significance.

\section{RESULTS}

\section{Zooplankton}

Of the 45 taxa that were identified in the $5 \mathrm{~min}$ samples from the 6 transects, the 15 dominant groups are listed in Table 2. All species were well known from several studies of zooplankton in this area (e.g. Atkinson 1989, Ward 1989, Ward et al. 1990). The numbers of the most dominant species in each 5 min sample are shown in Fig. 4, grouped according to size. The $y$-axes for each plot are the counts of individuals from 5 min samples; prion and copepod numbers are given in hundreds and larger zooplankton in tens. (The zooplankton numbers should be divided by 116 to find approximate numbers per cubic metre.) These counts need to be multiplied by a different factor for each species in order to relate them to biomass. For most species length/weight measurements have been obtained from the literature. For individuals identified as either Thysanoessa vicina or $T$. macrura, for which no published information was available, new length and dry weight measurements of specimens are given in Table 2 .

The species or life-stages that predominated varied between transects (Fig. 4), although among the cope- 


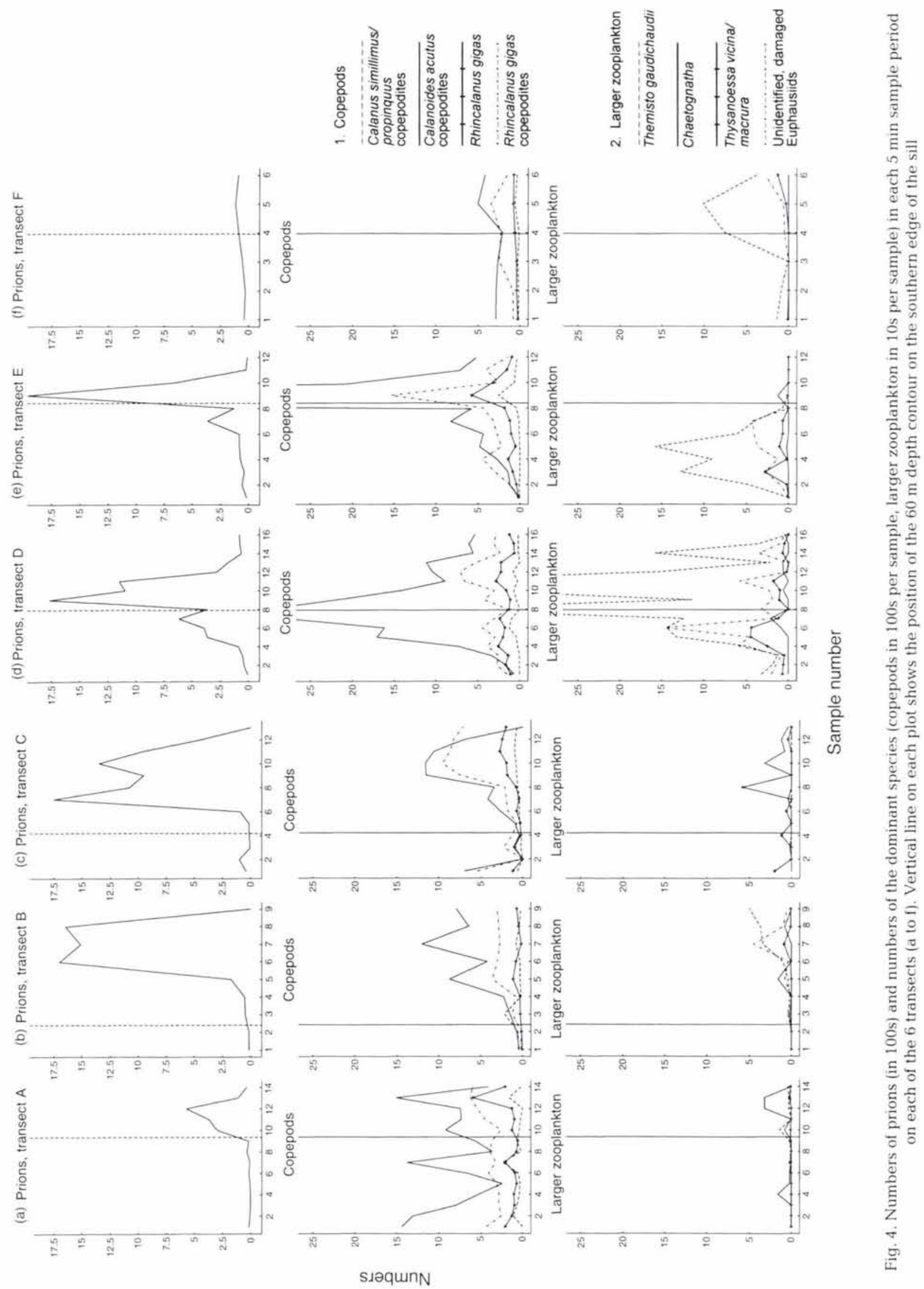


Table 2. Dominant zooplankton in pump samples

\begin{tabular}{|c|c|c|c|c|c|}
\hline Taxon & Stage & Length (mm) & Weight (mg dry) & Weight (mg wet) & Source \\
\hline Chaetognatha & & $10-40$ & 4.0 & 50 & $\begin{array}{l}\text { This study } \\
\text { Hagen (1988) }\end{array}$ \\
\hline Tomopteris sp. & & 36 & 44.5 & 505 & Hagen (1988) \\
\hline Calanus simillimus & $\mathrm{C} 6 \mathrm{~F}$ & $\begin{array}{l}3.5-3.65 \\
3.1-3.6\end{array}$ & 0.13 & & $\begin{array}{l}\text { P. Ward (pers. comm.) } \\
\text { Vervoort (1951) } \\
\text { Vervoort (1957) }\end{array}$ \\
\hline C. simillimus & $\mathrm{C} 6 \mathrm{M}$ & 3.42 & & & Vervoort (1951) \\
\hline C. simillimus copepodites & C5 & & 0.09 & & P. Ward (pers, comm.) \\
\hline Calanus propinquus & $\mathrm{C} 6 \mathrm{~F}$ & $\begin{array}{l}4.80-5.30 \\
4.75-6.00\end{array}$ & 0.5 & & $\begin{array}{l}\text { P. Ward (pers. comm.) } \\
\text { Vervoort (1951) } \\
\text { Vervoort (1957) }\end{array}$ \\
\hline C. propinquus copepodites & $\mathrm{C} 5$ & & 0.35 & & P. Ward (pers. comm.) \\
\hline Calanoides acutus & $\mathrm{C} 6 \mathrm{~F}$ & $\begin{array}{l}5.50-5.65 \\
4.75-5.70\end{array}$ & 0.304 & & $\begin{array}{l}\text { P. Ward (pers. comm.) } \\
\text { Vervoort (1951) } \\
\text { Vervoort (1957) }\end{array}$ \\
\hline C. acutus copepodites & $\mathrm{C} 5$ & & 0.257 & 1.8 & P. Ward (pers. comm.) \\
\hline Rhincalanus gigas & $\mathrm{C} 6 \mathrm{~F}$ & $\begin{array}{c}8-10 \\
7.7-9.3\end{array}$ & 0.8 & 10.9 & $\begin{array}{l}\text { P. Ward (pers. comm.) } \\
\text { Vervoort (1951) } \\
\text { Vervoort (1957) }\end{array}$ \\
\hline R. gigas copepodites & $\begin{array}{l}\text { C5 } \\
\text { C4 }\end{array}$ & & $\begin{array}{l}0.68 \\
0.5\end{array}$ & 5.15 & $\begin{array}{l}\text { P. Ward (pers. comm.) } \\
\text { P. Ward (pers. comm.) }\end{array}$ \\
\hline Themisto gaudichaudii & & & 6.0 & & P. Ward (pers. comm.) \\
\hline T. gaudichaudii juveniles & & & 3.0 & & Hagen (1988) \\
\hline Euphausia frigida & & 15 & 2.7 & & Ward et al. (1990) \\
\hline Thysanoessa vicina/macrura & & 9.5 & 0.96 & & This study \\
\hline
\end{tabular}

pods, copepodites of Calanoides acutus were the most abundant form on all of the 6 transects. Rhincalanus gigas copepodites were the next most abundant group. Among the taxa of larger zooplankton, Themisto gaudichaudii were predominant on 4 transects and chaetognaths were predominant on 2 .

The samples collected during this survey showed pronounced patchiness. Species either varied independently, or co-occurred as with some of the copepods on Transects $\mathrm{C}$ and $\mathrm{E}$ or showed a negative association such as that seen on Transect D, where 2 Themisto gaudichaudii peaks alternate with a very large maximum of Calanoides acutus copepodites. In Fig. 4 a vertical line has been used to mark the southern extent of the sill area that forms an important feature in the strait, and it can be seen that more zooplankton maxima occur at or to the south of this line than to the north. The 5 min observations of zooplankton were examined separately for each transect to examine the degree of autocorrelation between successive records. No significant autocorrelation was found. The peak numbers for the zooplankton species were also converted into dry weights in Table 3 , using the factors shown in Table 2.

\section{Bird observations}

Fig. 5 shows all bird records to the nearest minute, with sitting and feeding birds shown as solid bars, plotted against distance with the common bathymetric location point ( $60 \mathrm{~m}$ depth on the southern sill slope) made the zero point of the $x$-axis. The $1 \mathrm{~min}$ bins were examined separately for each transect for autocorrelation between successive records. They were found to be significantly autocorrelated for bin sizes up to $3 \mathrm{~min}$ in length, but not above. Since the numbers of foraging prions were to be compared with zooplankton samples gathered over $5 \mathrm{~min}$ intervals, bird records were pooled into $5 \mathrm{~min}$ bins. These pooled numbers are plotted in Fig. 4 against time. Prions foraged using 3 methods: plunge diving; pecking while sitting on the surface; and hydroplaning. When hydroplaning, the prions moved forward into the wind on outstretched wings using their feet for propulsion and keeping their bills in the water. When winds were below 25 knots, as was the case during Transects A, B, and C, the only foraging mode observed was that of sitting on the surface. At 25 knots, prions began to use hydroplaning, and about $10 \%$ of the prions foraging on Transect D were 

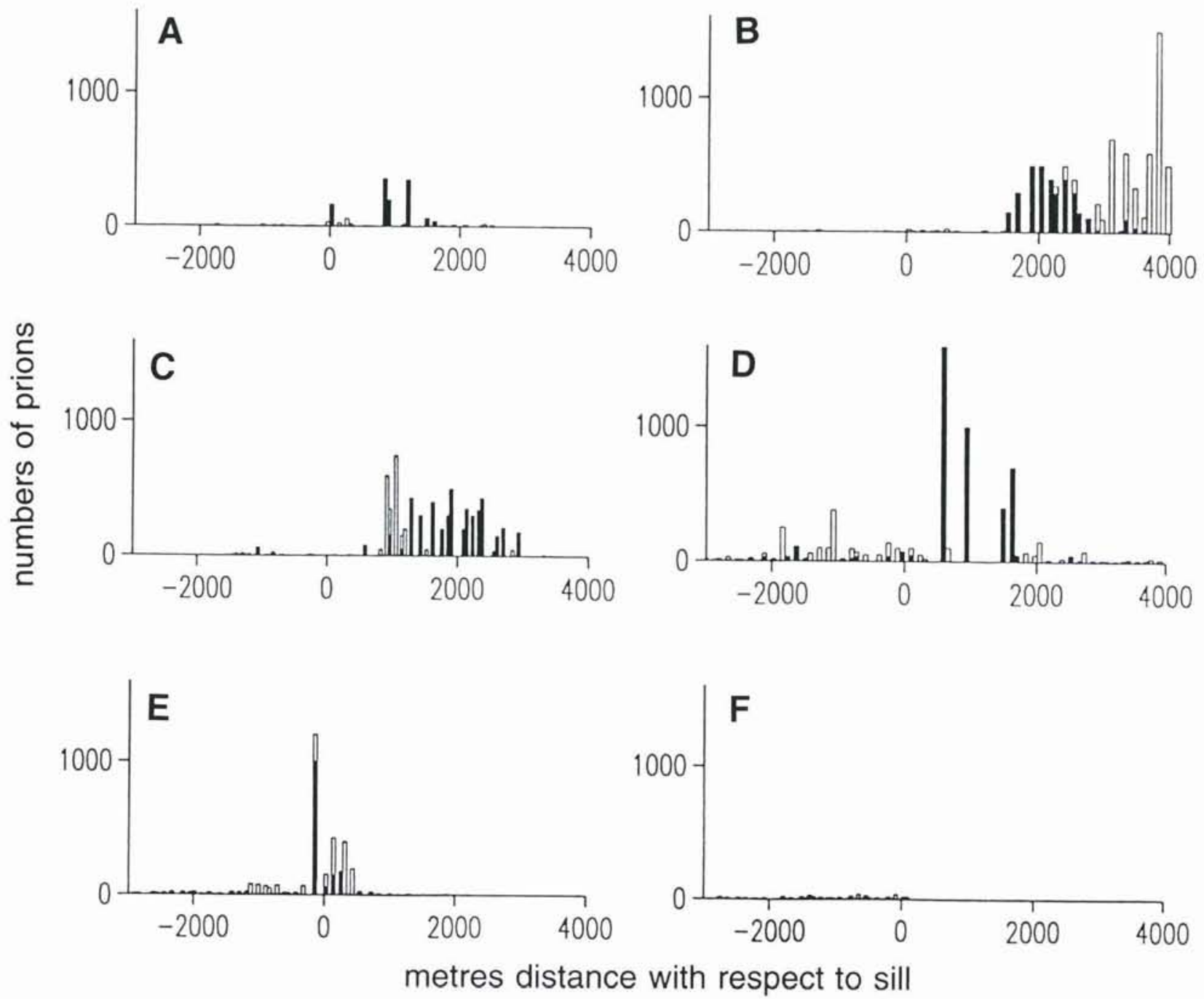

Fig. 5. Numbers of prions along each transect, relative to sill. Clear bars indicate flying birds; filled bars indicate sitting or foraging birds. Zero on the $x$-axis indicates the common location point: $60 \mathrm{~m}$ depth contour to the south of the sill (see text for full explanation)

hydroplaning. On Transect E, during which winds were 25 knots, most foraging prions employed hydroplaning. Plunging was observed only twice, both times on Transect E.

The plots of the distribution of prions that were foraging or sitting on the water at a bin size equivalent to $100 \mathrm{~m}$ travel (Fig. 5) shows that the prions occurred as a series of smaller patches within larger meta-patches on 5 of the transects. These fine-scale patches occurred at a scale of 50 to $150 \mathrm{~m}$, considerably larger than our minimum counting interval of about $20 \mathrm{~m}(0.2 \mathrm{~min})$. At a still finer scale, prions were distributed on the water in lines parallel to the wind, about 5 to $15 \mathrm{~m}$ apart, as judged from the body lengths of birds photographed during the transects. Birds within these bands often were less than a body length apart and pecked at the water with their heads close together at the centre of the band.

\section{Zooplankton-bird relationships}

The distributions of prions along 5 of the 6 transects were strongly peaked over regions where zooplankton was concentrated (Fig. 4). Examination of Figs. 4 \& 5 shows that the peak numbers of prions consistently occurred at or south of the $60 \mathrm{~m}$ contour on the south side of the sill. Cross-correlations between dominant zooplankton and total prion numbers pooled over $5 \mathrm{~min}$ were calculated. The large size of the samples relative to aggregation size of both birds and their prey means that a slight offset in time of observations between the birds and their prey (such as that created by the distance between the pump sampler and the bird observation area) could be reflected in a lag of 1 whole sample in either direction between positively correlated observations. Table 3 shows the cross-correlations that were 
Table 3. Zooplankton species significantly cross-correlated with prions at $95 \%$ level of probability. Dry weight conversion made using data in Table 2

\begin{tabular}{|c|c|c|}
\hline $\begin{array}{l}\text { Zooplankton } \\
\text { species }\end{array}$ & $\begin{array}{l}\text { Zooplankton } \\
\text { greatest peak } \\
\text { (per sample) }\end{array}$ & $\begin{array}{c}\text { Zooplankton } \\
\text { dry weight } \\
\text { (mg) }\end{array}$ \\
\hline \multicolumn{3}{|l|}{ Transect A } \\
\hline Chaetognatha & 32 & 128 \\
\hline Calanoides acutus & 32 & 10 \\
\hline Rhincalanus gigas & 592 & 474 \\
\hline R. gigas copepodites & 624 & 374 \\
\hline \multicolumn{3}{|l|}{ Transect B } \\
\hline C. acutus copepodites & 1200 & 360 \\
\hline R. gigas copepodites & 360 & 216 \\
\hline Themisto gaudichaudii & 50 & 300 \\
\hline \multicolumn{3}{|l|}{ Transect C } \\
\hline $\begin{array}{l}\text { Calanus simillimus/ } \\
\text { propinquus copepodites }\end{array}$ & 96 & 19 \\
\hline C. propinquus & 8 & 4 \\
\hline Rhincalanus gigas & 272 & 218 \\
\hline R. gigas copepodites & 952 & 571 \\
\hline \multicolumn{3}{|l|}{ Transect D } \\
\hline C. propinquus & 48 & 24 \\
\hline C. acutus copepodites & 3024 & 907 \\
\hline Themisto gaudichaudii & 496 & 2976 \\
\hline \multicolumn{3}{|l|}{ Transect E } \\
\hline Chaetognatha & 13 & 52 \\
\hline $\begin{array}{l}\text { C. simillimus/ } \\
\text { propinquus copepodites }\end{array}$ & 256 & 51 \\
\hline C. acutus & 16 & 5 \\
\hline C. acutus copepodites & 13376 & 4013 \\
\hline R. gigas & 576 & 461 \\
\hline R. gigas copepodites & 1536 & 922 \\
\hline \multicolumn{3}{|l|}{ Transect $\mathrm{F}$} \\
\hline R. gigas & 76 & 61 \\
\hline T. gaudichaudii & 101 & 606 \\
\hline Thysanoessa vicina/macrura & 13 & 13 \\
\hline
\end{tabular}

significant at the $95 \%$ confidence level between birds and zooplankton species, allowing for this amount of offset. Significant correlations occurred on at least 1 occasion between prions and each of the dominant zooplankton taxa, except for Calanus simillimus and unidentified euphausiids. Concentrations of prions were mostly recorded where there was prey, but there were high concentrations of prey without prions.

Restricting bird observations to exclude flying birds resulted in a large number of intervals where either no birds or very low numbers were present (see Fig. 5), so it was not possible to perform correlation analyses with these data. Intervals were classified into those where 20 or less non-flying birds were recorded in $5 \mathrm{~min}$ and those where there were more than 20. Zooplankton counts were pooled into the same 2 classes that had been used for the plots, i.e. copepods and larger zooplankters, and these were also classified into records containing either few individuals or many according to thresholds selected from frequency
Table 4. Occurrence of foraging and sitting birds with different classes of zooplankton species. $n$ : number of observations (absent + present)

\begin{tabular}{|lrrrrr|}
\hline Birds & \multicolumn{4}{c|}{ Zooplankton } & $\mathrm{n}$ \\
& $\begin{array}{c}\text { Copepods } \\
\text { Absent Present }\end{array}$ & $\begin{array}{c}\text { Larger zooplankton } \\
\text { Absent Present }\end{array}$ & \\
\hline Absent & 30 & 14 & 30 & 14 & 44 \\
Present & 7 & 19 & 15 & 11 & 26 \\
$\mathrm{n}$ & 37 & 33 & 45 & 25 & 70 \\
\hline
\end{tabular}

distributions. For copepods the threshold concentration chosen was 1200 and for larger zooplankters 50 . Table 4 shows a 2-way contingency table for each class. For copepods, on 19 out of the 26 occasions when there were more than 20 birds feeding or sitting on the water, copepods also exceeded the chosen threshold $\left(\chi^{2}=11.16, p<0.001\right)$. Conversely for the larger species, slightly less than half of the intervals with more than 20 birds had zooplankton peaks, and this result was not significant $(p>0.05)$.

\section{DISCUSSION}

\section{Zooplankton sampling}

The new pump sampler has 2 main advantages over earlier designs: the removal of water from the back of the net at a steady, recorded rate and an easy and adaptable means of sub-sampling. The pump method gives a more precise sample volume than is possible with standard nets where sample volume is closely linked to towing speed and degree of clogging of the net. Sub-sample size is regulated by time, and if visual inspection shows that the samples contain too few or too many individuals for counting, the time allowed per sub-sample can be adjusted. [See also Powlik et al. (1991) for a comparison of nets and pumped systems.]

An important characteristic of any net sampler is its selectivity for different species. This net successfully caught copepod stages probably below the size range likely to be filtered by feeding prions. It is also likely to be effective in sampling the largest copepods and other large species of zooplankton expected in the diets of prions. Although it should catch the required size range of organisms, the sampler was used during the daytime and in the most brightly lit part of the water column, potentially causing avoidance. Fast swimming species such as krill are very likely to avoid the net at the speeds used (Everson \& Bone 1986). Small euphausiids such as Thysanoessa spp. were recorded from the net and it was notable that other 
euphausiids that were caught were damaged. These fragments may constitute a fraction of damaged and disoriented krill, such as that described by Obst (1985). The build up of a body of water in front of a net would exacerbate the problem of net avoidance by fastswimming zooplankters by allowing them to sense its approach sooner; the removal of water at the back of this net thus minimises avoidance. The use of an expanding nose cone and the total surface area of the net meant that the system would have filtered just about $100 \%$ of the water presented to it. Also the scavenging rate of the pump ensured that there was no delay in evacuating the cod-end.

\section{Location of zooplankton aggregations}

The zooplankton aggregations selected by the foraging prions were mainly located to the south of the sill. Concentrations of zooplankton related to bottom topography are often described, and a number of hypotheses have been put forward for their occurrence (e.g. Gagnon \& Lacroix 1983, Lewis \& Thomas 1986). The presence of aggregations around the southern side of the sill could be attributed to concentration by phototactic swimming of zooplankton against a downwards-flowing current following the bottom, descending away from the coastline (cf. Alldredge \& Hamner 1980) Alternatively, existing aggregations occurring at various depths to the north of the sill could have been forced into the surface layer by the southerly tidal current as it travelled over the sill.

\section{Zooplankton-bird relationships}

The analysis using only sitting and feeding birds demonstrated that the association between birds and copepod maxima was significant across all 6 transects, whereas any association between birds and other species was not sufficiently strong to be detected from the pooled results. The inclusion of flying birds would not be expected to produce a clear picture of the pattern of foraging behaviour, especially at the $1 \mathrm{~min}$ scale of the bird observations. However, at the $5 \mathrm{~min}(460 \mathrm{~m})$ scale of the zooplankton observations, evidence for specific associations between total birds and zooplankton abundance emerged. The dry weight estimates in the last column of Table 3 indicate which aggregations were the best food sources available to the prions, and they were equally as likely to be copepodite stages of the large copepods as amphipods or euphausiids. The results of the cross-correlation analysis using total bird numbers showed that some of the significant correlations were with very low copepod biomass; these may have arisen by chance, when concentrations of different species occurred within 1 sampling interval.

Prince (1980) reported on a survey of the diet of Pachyptila desolata using food samples regurgitated by adults about to feed chicks: $90 \%$ of the food was made up of crustaceans. Sub-dividing the crustacean fraction, over $50 \%$ by weight was krill, nearly onethird large copepods and the remainder amphipods, other euphausiids and mysiids. The proportions of potential prey sampled in this study are very different from this. Although avoidance may have caused low catches of krill, significant numbers of euphausiid fragments were sometimes caught in the net in the present study; dead or damaged prey would be a potential source of these species to prions in daylight. Live specimens of the largest prey species would not be expected to occur frequently within the birds' foraging range in daylight; therefore night feeding could be prions' source of euphausiids. Little information on nocturnal feeding is available, but it is reported that it may be important to $P$. desolata, who feed their chicks after dusk (Croxall \& Prince 1980). Of the 90 prions sampled by Prince (1980), 1 was excluded from his main analysis because of its exceptional food composition. It contained a large number $(\sim 41000)$ of 1 species of copepod (Calanoides acutus), around 160 times the average for this species found in the other birds examined. This individual could have fed on an aggregation of the type described in the present paper.

Liddle (1994) and Reid et al. (1997) analysed Pachyptila spp. stomach contents in different years and found evidence of prey switching between euphausiids to amphipods and copepods. Veit et al. (1993) found a significant spatial relationship offshore between prions and krill detected acoustically, using data from the same cruise discussed in the present paper. These authors found only 5 out of 14 individuals taken near an offshore krill patch had eaten krill, unlike other bird species examined at the same time, possibly suggesting that prions did not have equal access to the patch. The present study provides evidence of opportunistic feeding, with the finding that significant correlations occurred on at least 1 occasion between prions and all the dominant zooplankton groups counted, apart from unidentified euphausiid remains (Table 3). Prince (1980) also described 2 methods of feeding seen in P. desolata. Hydroplaning involved fast forward propulsion through the water, either seizing or filtering prey with the head below the water, the other was surface filtering in a swimming or static position. Only the technique of seizing prey would suggest any sort of local choice of prey items; selectivity otherwise could be achieved by the dimensions of the filtering lamellae in their bills and the choice of feeding site. 


\section{Small-scale observations on feeding birds}

The arrangement of the foraging prions in lines parallel to the wind and 5 to $15 \mathrm{~m}$ apart suggests that, at the smallest scales of observation, planktonic prey may have been concentrated in surface convergences associated with Langmuir circulation. Langmuir circulation results in alternating divergences and convergences parallel to the wind, with organisms and particles that float being concentrated in the convergences (Barstow 1983, Leibovich 1983). Convergences may vary from 2 to $300 \mathrm{~m}$ apart, and Stavn (1971) demonstrated that Langmuir circulation is capable of concentrating vertically migrating, photosensitive zooplankton.

Brown (1980) has observed surface-foraging phalaropes, gulls and terns feeding in convergences associated with Langmuir circulation, but not between them. More recently, Decker (1996) described northern fulmars Fulmarus glacialis and shearwaters Puffinus spp. foraging on plankton concentrated by Langmuir circulation in lines at the surface. Our observations of prions utilising what appeared to be Langmuir circulation supports the notion that this physical process may be of considerable importance in providing concentrations of planktonic prey in the surface waters of the ocean. The value of these concentrations to marine birds would be enhanced by the presence of foam and other flotsam that would mark their location.

\section{Location of zooplankton by birds}

Little is known about how prions or other seabirds locate their prey. If foraging locations are spatially fixed, as occurs when currents interact with bathymetry to create fronts (e.g. Schneider et al. 1987, 1990), then birds may learn where prey are likely to be available and to return repeatedly to that location to forage (Nisbet 1983, Irons 1992, Prince et al. 1992, Becker et al. 1993). Prions are regularly observed feeding downstream of rocks that break the surface in Stewart Strait; they feed in the turbulent water caused by the strong tidal current (Reid et al. 1997). This may be because local physical features force prey up to the surface. In this study many zooplankton aggregations were located over the southern part of the sill or to the south of the sill. If this is a common occurrence at the site that the birds seem to favour, the birds may have learnt that this is a good feeding site, recognising the location by any one of a number of visual cues, such as those provided by lines of foam and other flotsam, and once foraging had begun, by other birds that were actively foraging.

It has been suggested that sight is not the most important sense that prions use for locating prey. Nevitt et al. (1995) presented evidence that prions near South Georgia reacted to dimethyl sulphide, a scented compound released from phytoplankton while being fed on by zooplankton. The relationship between the wind speed and direction (given in Table 1) and the location of the peak numbers of foraging prions with respect to the southern limit of the sill area (Fig. 5) could give some support to the hypothesis that olfactory cues are the signals used by birds to locate prey. For the first 3 transects ( $A$ to $C$ ) the wind was moderate, from the northeast for the first 2 runs and from the west for the third. The 3 prion peaks on these transects occurred well to the south of the sill, although there were zooplankton peaks elsewhere. The last 3 transects (D to F) were carried out when the wind was stronger and from the southeast. Two of these, D and E, had prion maxima at, or close to, the southern limit of the sill, i.e. further to the north than the first 3 . The final transect, F, did not encounter any significant prion peaks. The prions on Transect $\mathrm{D}$, located over a large concentration of Calanoides acutus, also had several other zooplankton maxima that they might have chosen, including some to the south of their actual location.

\section{CONCLUSIONS}

Zooplankton was patchily distributed, with different taxa sometimes varying together and other times varying separately.

Every prion maximum coincided with a zooplankton peak and these were from different taxa; there were also numerous zooplankton peaks without associated prions.

When bird observations were restricted to sitting or feeding birds only, they were significantly associated with peaks in pooled copepod numbers. No significant relationship could be shown for these birds with pooled numbers of the larger zooplankton species.

On each occasion where a prion concentration was observed the location was consistent, the maxima occurring around the southern boundary of the sill that transects the strait.

There was a small change in the location of major prion concentrations coincident with a change in the strength and direction of the wind.

Acknowledgements. C.G. wrote the paper and performed the data analysis, D.G.B. designed and built the zooplankton sampler, J.M.P. sorted and identified the zooplankton and I.E. and G.L.H. designed and managed the surveys. A.W.A.M. gave statistical advice. Contributions from the following are also gratefully acknowledged: Peter Ward for copepod weights, measurements and expertise, Andy Wood for database management, and Keith Reid, John Croxall and 2 anonymous referees for many helpful comments on the manuscript. Thanks are also due to the team of bird observers: N. Harri- 
son, D. Heinemann, R. Veit and M. Whitehouse; the zooplankton scientists and the crew of the RRS 'John Biscoe' for that season. G.L.H. was supported by National Science Foundation Grant DPP-8318464.

\section{LITERATURE CITED}

Alldredge AL, Hamner WM (1980) Recurring aggregation of zooplankton by a tidal current. Estuar Coast Mar Sci 10: $31-37$

Anon (1974) The antarctic pilot, 4th edn. The Hydrographer of the Navy, Taunton (Suppl No. 9, 1989)

Atkinson A (1989) Distribution of six major copepod species around South Georgia in early summer. Polar Biol 9:353-363

Barstow SF (1983) The ecology of Langmuir circulation: a review. Mar Environ Res 9:211-236

Becker PH, Frank D, Sudmann SR (1993) Temporal and spatial pattern of common tern (Sterna hirundo) foraging in the Wadden Sea. Oecologia 93:389-393

Brown RGB (1980) Seabirds as marine animals. In: Burger J, Olla B, Winn HE (eds) Behaviour of marine animals, Vol 4, Marine birds. Plenum Press, New York, p 1-39

Croxall JP, Prince PA (1980) Food, feeding ecology and ecological segregation of seabirds at South Georgia. Biol J Linn Soc 14:103-131

Croxall JP, Prince PA (1987) Seabirds as predators on marine resources, especially krill, at South Georgia. In: Croxall JP (ed) Seabirds: feeding, ecology and role in marine ecosystems. Cambridge University Press, Cambridge, p 347-368

Croxall JP, Prince PA, Ricketts C (1985) Relationships between prey life-cycles and the extent, nature and timing of seal and seabird predation in the Scotia Sea. In: Siegfried WR, Condy PR, Laws RM (eds) Antarctic nutrient cycles and food webs. Springer-Verlag, Berlin, p 516-533

Decker MB (1996) Influences of oceanographic processes on seabird ecology. PhD thesis, University of California, Irvine

Erikstad KE, Moum T, Vader W (1990) Correlations between pelagic distribution of Common and Brünnich's Guillemots and their prey in the Barents Sea. Polar Res 8:77-87

Everson I, Bone DG (1986) Effectiveness of the RMT8 system for sampling krill (Euphausia superba) swarms. Polar Biol 6:83-90

Gagnon M, Lacroix G (1983) The tidal transport and retention of zooplankton in relation to a sill in a tidal estuary. J Plankton Res 5:289-303

Hagen W (1988) On the significance of lipids in Antarctic zooplankton. Ber Polarforsch 49:1-129

Harrison NM, Whitehouse MJ, Heinemann D, Prince PA, Hunt GL Jr, Veit RR (1991) Observations of multispecies flocks around South Georgia. Auk 108:801-810

Heinemann D, Hunt GL Jr, Everson I (1989) Relationships between the distributions of marine avian predators and their prey, Euphausia superba, in Bransfield Strait and southern Drake Passage, Antarctica. Mar Ecol Prog Ser 58:3-16

Hunt GL Jr, Everson I, Heinemann D, Viet RR (1986) Distribution of krill, marine birds, and antarctic fur seals in the waters off the western end of South Georgia Island. Antarctic J US 21:201-203

Hunt GL Jr, Harrison NM (1990) Foraging habitat and prey taken by least auklets at King Island, Alaska. Mar Ecol Prog Ser 65:141-150

Hunt GL Jr, Heineman D, Everson 1 (1992) Distributions and predator-prey interactions of macaroni penguins. Antarctic fur seals, and Antarctic krill near Bird Island, South Georgia. Mar Ecol Prog Ser 86:15-30
Irons D (1992) Aspects of foraging behavior and reproductive biology of the black-legged kittiwake. PhD thesis, University of California, Irvine

Leibovich S (1983) The form and dynamics of Langmuir circulations. Annu Rev Fluid Mech 15:391-427

Lewis AG, Thomas AC (1986) Tidal transport of planktonic copepods across the sill of a British Columbian fjord. J Plankton Res 8:1079-1089

Liddle GM (1994) Interannual variation in the breeding biology of the Antarctic prion Pachyptila desolata at Bird Island, South Georgia. J Zool 234:125-139

Nevitt GA, Veit RR, Kareiva P (1995) Dimethyl sulphide as a foraging cue for Antarctic Procellariiform seabirds. Nature (Lond) 376:680-682

Nisbet ICT (1983) Territorial feeding by common terns. Colon Waterbirds 6:64-70

Obst B (1985) Densities of Antarctic seabirds at sea and the presence of krill Euphausia superba. Auk 102: $540-549$

Payne RW, Lane PW, Ainsley AE, Bicknell KE, Digby PGN, Gower JC, Harding SA, Leech PK, Simpson HR, Todd AD, Verrier PJ, White RP, Tunnicliffe-Wilson G, Paterson LJ (1987) GENSTAT 5 reference manual. Oxford University Press, Oxford

Powlik JJ, St John MA, Blake RW (1991) A retrospective of plankton pumping systems, with notes on the comparative efficiency of towed nets. J Plankton Res 13: 901-912

Prince PA (1980) The food and feeding ecology of Blue petrel Halobaena caerulea and Dove prion Pachyptila desolata. J Zool 190:59-76

Prince PA, Wood AG, Barton T, Croxall JP (1992) Satellite tracking of wandering albatrosses (Diomeded exulans) in the South Atlantic. Antarct Sci 4:31-36

Reid K, Croxall JP, Edwards TM (1997) Interannual variation in the diet of the Antarctic prion Pachyptila desolata at South Georgia. Emu 97

Schneider DC, Harrison NM, Hunt GL. Jr (1987) Variation in the occurrence of marine birds at fronts in the Bering Sea. Estuar Coast Mar Sci 5:241-258

Schneider DC, Harrison NM, Hunt GL Jr (1990) Seabird diet at a front near the Pribilof Islands, Alaska. Stud Avian Biol $14: 61-66$

Schneider DC, Piatt JF (1986) Scale-dependant correlation of seabirds with schooling fish in a coastal ecosystem. Mar Ecol Prog Ser 32:237-246

Stavn RH (1971) The horizontal-vertical distribution hypothesis: Langmuir circulations and Daphnia distribution. Limnol Oceanogr 16:453-466

Veit RR, Silverman ED, Everson 1 (1993) Aggregation patterns of pelagic predators and their principal prey, Antarctic krill, near South Georgia. J Anim Ecol 62:551-564

Vervoort W (1951) Plankton copepods from the Atlantic sector of the Antarctic. North-Holland Publishing Company, Amsterdam

Vervoort W (1957) Copepods from Antarctic and sub-Antarctic plankton samples. BANZARE, Adelaide

Ward P (1989) The distribution of zooplankton in an Antarctic fjord at South Georgia during summer and winter. Antarct Sci 1:141-150

Ward P, Atkinson A, Peck JM, Wood AG (1990) Euphausiid life cycles and distribution around South Georgia. Antarct Sci 2:43-52

Woodby D (1984) The April distribution of murres and prey patches in the southeastern Bering Sea. Limnol Oceanogr 29:181-188

Manuscript received: February 4, 1997

Revised version accepted: May 29, 1997 